\title{
Tumor escape and progression of HER-2/neu negative breast cancer under immune pressure
}

\author{
Maciej Kmieciak', Kyle K Payne ${ }^{1}$, Michael O Idowu², Margaret M Grimes ${ }^{2}$, Laura Graham³, Maria-Libera Ascierto ${ }^{4}$, \\ Ena Wang ${ }^{4}$, Xiang-Yang Wang ${ }^{5}$, Harry D Bear ${ }^{3}$ and Masoud H Manjili $i^{*}$
}

\begin{abstract}
Background: Emerging data from pre-clinical and clinical studies suggest that HER-2/neu-specific T cell responses could induce HER-2/neu antigen loss in the tumor cells. These data suggest that patients with HER-2/neu negative breast cancer might have had HER-2/neu positive premalignant lesions in the past that progressed to HER-2/neu negative breast cancer under HER-2/neu-specific immune pressure.
\end{abstract}

Methods: We conducted a pilot study in patients with HER-2/neu positive and HER-2/neu negative breast cancers as well as a patient with ductal carcinoma in situ (DCIS). HER-2/neu expression was determined by FISH. HER-2/ neu-specific T cell responses were determined by using IFN- $\gamma$ ELISA. Expression of IFN- $\gamma$ R $\alpha$ in the tumors was determined by immunohistochemistry analysis of paraffin-embedded tissues.

Results: We determined that majority of (10 of 12) patients with HER-2/neu negative breast cancer had HER-2/neuspecific IFN- $\gamma$ producing $T$ cell responses which was stronger than those in patients with HER-2/neu positive tumors. Such immune responses were associated with nuclear translocation of IFN- $\gamma$ R $\alpha$ in their tumor cells. Patient with DCIS also showed HER-2/neu-specific T cell responses.

Conclusion: These data suggest that conducting retrospective studies in patients with HER-2/neu negative breast cancers and prospective studies in patients with HER-2/neu positive DCIS can determine whether HER-2/neu negative invasive carcinomas arise from HER-2/neu positive DCIS under the immune pressure.

\section{Introduction}

In recent years, there has been emerging evidence from both pre-clinical and clinical studies, including our own, which challenge the one-sided view of the role of IFN- $\gamma$ producing $\mathrm{T}$ cells in protecting the host against cancers. For example, IFN- $\gamma$ was shown to promote immune editing and subsequent tumor escape in the CT26 colon carcinoma by down-regulation of the expression of gp70 immunogenic tumor antigen at the mRNA levels [1]. Recently, it was demonstrated that inhibiting expression of IFN- $\gamma$ receptor (R) by forcing expression of the dominant negative IFN- $\gamma \mathrm{R}$ reduced the ability of renal carcinoma cells to metastasize [2]. We have also reported that immunotherapy of rat neu expressing breast cancer elicits neu-specific IFN- $\gamma$ producing CD $8+\mathrm{T}$ cells that

\footnotetext{
* Correspondence: mmanjili@vcu.edu

'Department of Microbiology \& Immunology, Virginia Commonwealth University Massey Cancer Center, 401 College Street, Richmond VA 23298, USA

Full list of author information is available at the end of the article
}

in turn facilitate breast cancer recurrence of neu Antigen Negative Variant (ANV) tumors following initial rejection of the neu positive Mouse Mammary Carcinoma (MMC) tumor cells in immunocompetent mice $[3,4]$. The tumor antigen loss was due to hypermethylation of the neu promoter and loss of neu both at mRNA and protein levels [3,5], resulting in escape of the tumor from further neu-specific immune responses. On the clinical front, elevated serum levels of IFN- $\gamma$ in uveal melanoma patients correlate with the spread of metastasis and represent a negative prognostic marker [6]. It was recently shown that HER-2/neu-targeted vaccination of patients who had HER-2/neu+ ductal carcinoma in situ (DCIS) elicited HER-2/neu-specific IFN- $\gamma$ producing CD8 + T cell responses which resulted in HER-2/ neu antigen loss [7]. Although the authors considered this HER-2/neu loss a positive outcome of the immune response, no follow-up studies have been performed to determine whether patients with HER-2/neu loss in their DCIS tumors might end up with recurrence of

\section{Biomed Central}


invasive HER-2/neu positive or negative breast cancers. Several other correlative or in vitro studies suggest potentially negative effects of some immune responses in breast cancer. Matkowski and Sheu both showed in cohorts of 88 and 24 patients with operable breast cancer, respectively, that relapse or disease progression was associated with strong CD8 $+\mathrm{T}$ cell infiltration $[8,9]$. Interestingly, it was reported that HER-2/neu+ human prostate tumor cell lines, DU145 and PC-3, that responded to IFN- $\gamma$ (because of the expression of IFN- $\gamma$ $\mathrm{R} \alpha$ ), showed down-regulation of HER-2/neu expression whereas another prostate tumor cell line, $\mathrm{LNCaP}$, that failed to respond to IFN- $\gamma$ did not show any change in the expression of HER-2/neu [10]. Such failure of the $\mathrm{LNCaP}$ to respond to IFN- $\gamma$ was later shown to be due to the lack of JAK1 expression [11]. These findings prompted us to determine whether HER-2/neu-specific IFN- $\gamma$ producing $\mathrm{T}$ cell responses may be associated with HER-2/neu loss and progression to HER-2/neu negative breast carcinoma. To test this hypothesis, we conducted pilot studies in patients with HER-2/neu positive and HER-2/neu negative breast carcinoma to determine whether patients with HER-2/neu negative tumors had HER-2/neu-specific $\mathrm{T}$ cell responses that had been induced by HER-2/neu positive pre-malignant lesions in the past.

\section{Materials and methods Patient specimens}

Formalin-fixed paraffin-embedded tumor blocks were prepared from 15 patients with breast cancer among which 12 patients had HER-2/neu negative tumors and three patients had HER-2/neu positive tumors, as determined by fluorescence in situ hybridization (FISH). We also included two samples from a patient with ductal carcinoma in situ (DCIS). Peripheral blood mononuclear cells (PBMCs) and sera were also obtained from these patients and used for in vitro studies. This study was conducted under Institutional Review Board (IRB) protocol\# HM10920 at Virginia Commonwealth University. All patients had the capacity to give informed consent to participate in this research.

\section{IFN- $\gamma$ ELISA}

PBMCs were harvested from the blood of invasive breast cancer patients $(n=15)$ and two samples from a patient with DCIS. After Ficoll density gradient separation, PBMCs were cultured at $37^{\circ} \mathrm{C}$ for $2 \mathrm{hr}$, adherent cells were used for the generation of monocyte-derived DCs in the presence of GM-CSF (100 ng/ml) and IL-4 (50 $\mathrm{ng} / \mathrm{ml})$, as previously described by our group [12]. Floater cells were maintained with IL-2 $\left(40 \mathrm{U} / \mathrm{ml} / 10^{6}\right.$ cells $)$ in complete medium for 6-7 days until autologous DCs became available. The IL-2 maintained lymphocytes were then cultured with autologous DCs (4:1) in the presence or absence of recombinant HER-2/neu $(100 \mu \mathrm{g} / \mathrm{ml})$ or LPS $(10 \mu \mathrm{g} / \mathrm{ml})$. After $24 \mathrm{hs}$, supernatants were collected and subjected to IFN- $\gamma$ ELISA. We used a Human IFN- $\gamma$ ELISA set according to the manufacture's protocol (BD Pharmingen).

\section{Recombinant HER-2/neu protein}

The SK-BR-3 breast tumor line that overexpresses HER-2/neu was used to prepare the cDNA. Extracellular domain (ECD) and intracellular domain (ICD) of HER-2/neu were amplified using specific primers. ECD-forward: 5' AAA CTC GAG ATG GAG CTG GCG GCC TTG T 3' and reverse: 5' CTT AAG CTT CGT CAG AGG GCT GGC TCT CT 3'; ICD-forward: 5' AAA CTC GAG AAG CGA CGG CAG CAG AAG AT 3' and reverse: 5' CTT AAG CTT TCA CAC TGG CAC GTC CAG 3'. The orientation and integrity of inserted sequence were screened by detailed restriction analysis and sequencing. DNA encoding the ECD (aa 1-695) or ICD (aa 692-1256) were ligated into the expression vector pRSET (Invitrogen). The BL21 (DE3) pLys $S$ strain of $E$. coli was used for the expression the proteins. Proteins were purified under denaturing condition using Invitrogen ProBond Purification System. The ECD and ICD proteins were then dialyzed using $10 \mathrm{mM}$ Tris, $\mathrm{pH} 8.0$, and $20 \mathrm{mM}$ Tris $\mathrm{pH} 9.0$, respectively. Purity of the proteins was above $90 \%$ as determined by SDS-PAGE.

\section{Immunohistochemistry (IHC)}

In order to determine the status of IFN $-\gamma$ R $\alpha$ expression in the tumors IHC was performed using Dako automated immunostainer (Dako, Carpinteria, CA). We used anti-human IFN- $\gamma$ R $\alpha$ antibody (Santa Cruz Biotechnology Inc., Santa Cruz, CA). The antigen retrieval was achieved using a rice steamer. In order to circumvent the endogenous biotin activity, we used Dako Envision Dual Link System-HRP (Dako, Capinteria CA) in a twostep IHC technique, based on HRP labeled polymer which is conjugated with secondary antibodies. The labeled polymer does not contain avidin or biotin, thereby avoiding the non specific endogenous avidinbiotin activity in the sections. Positive and negative controls stained appropriately.

\section{Statistical analysis}

Statistical comparisons between groups were made using an unpaired Student's $t$ test with $\mathrm{P}<0.05$ being statistically significant. 


\section{Results}

Detection of HER-2/neu-specific IFN- $\gamma$ positive $T$ cell responses in HER-2/neu negative breast cancer patients Of 12 patients with HER-2/neu negative breast cancers (stages I-IIIA) ten patients showed HER-2/neu-specific IFN- $\gamma$ producing $\mathrm{T}$ cell responses (Figure 1A). All three patients with HER-2/neu positive breast cancer also showed HER-2/neu-specific T cell responses. As shown in Figure 1A, patients with HER-2/neu positive tumors showed significantly lower IFN $-\gamma$ responses to HER-2/neu compared to HER-2/neu negative patients (HER-2/neu positive: 22-120 ng/ml, HER-2/neu negative: $61-600 \mathrm{ng} / \mathrm{ml}, P=0.012)$. These responses were detected in the PBMC of patients prior to any treatment. Samples from a DCIS patient also showed HER2/neu-specific $\mathrm{T}$ cell responses (Figure $1 \mathrm{~B}$ ). No ECD-specific IgG antibody response was detected in the sera of these patients (data not shown). Patient characteristics are shown in Table 1.

\section{Nuclear translocation of IFN- $\gamma$ R $\alpha$ in the tumors of} patients with HER-2/neu-specific T cell responses

Since nuclear translocation of IFN- $\gamma \mathrm{R} \alpha$ is a consequence of IFN- $\gamma$ signaling in the tumor cells, we performed IHC analysis of the tumor lesions of the patients using anti-human IFN- $\gamma$ R $\alpha$ antibody. As can be seen in Figure $1 \mathrm{C}$, patients with HER-2/neu negative tumors and who had strong HER-2/neu-specific $\mathrm{T}$ cell responses showed an intense and uniform nuclear staining for IFN- $\gamma \mathrm{R} \alpha$ in their tumors while those with no $\mathrm{T}$ cell responses showed weak cytosolic staining for IFN- $\gamma$ $\mathrm{R} \alpha$ in their tumors. Patients with low levels of HER-2/ neu-specific IFN- $\gamma$ production (HER-2/neu positive or HER-2/neu negative tumors) showed weak and scattered

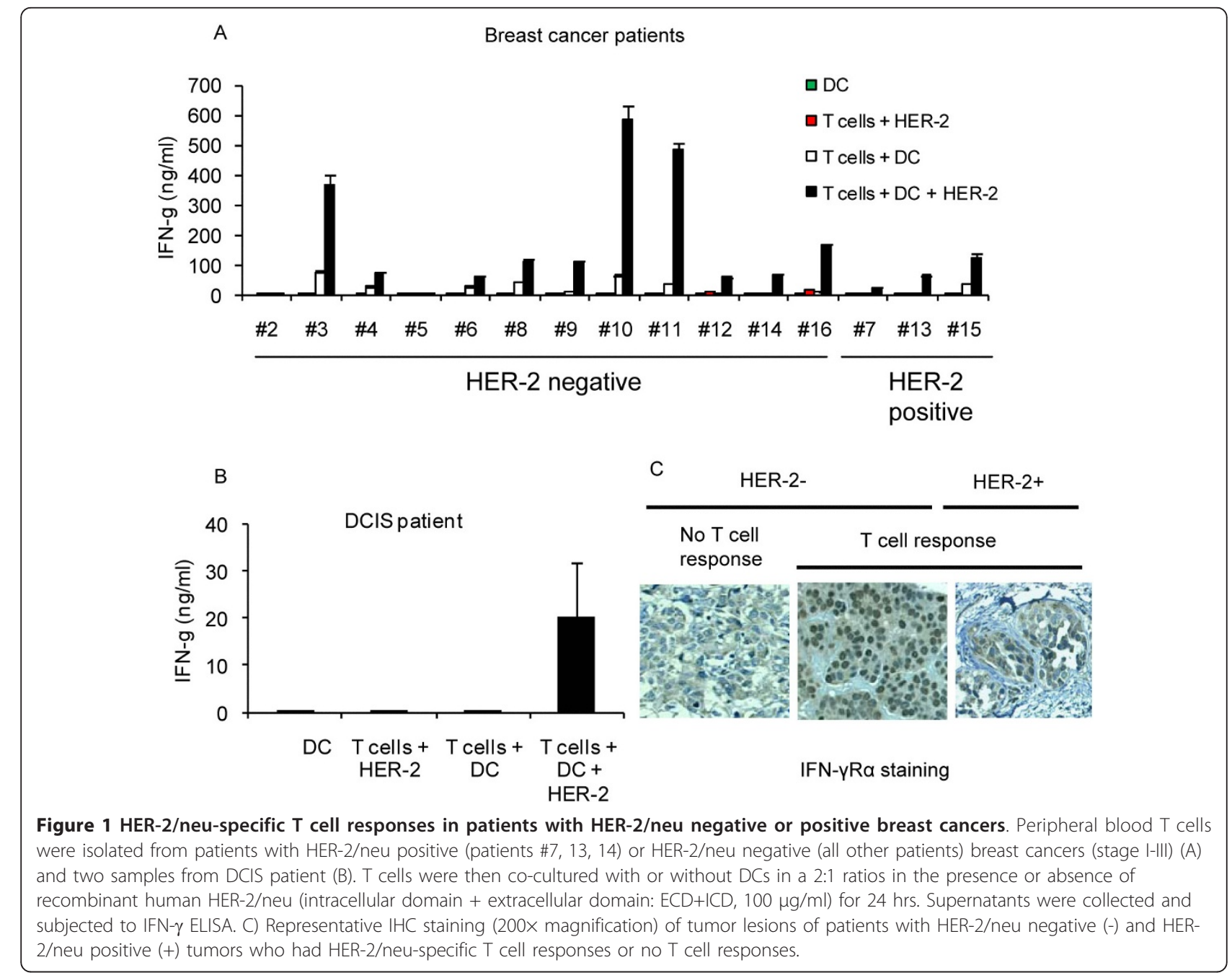


Table 1 Patients' characteristics

\begin{tabular}{lcc}
\hline Patients & Stage of tumor & HER-2 status \\
\hline$\# 2$ & । & - \\
\hline$\# 3$ & I & - \\
\hline$\# 4$ & IA & - \\
\hline$\# 5$ & IIB & - \\
\hline$\# 6$ & I & - \\
\hline$\# 8$ & IIA & - \\
\hline$\# 9$ & IA & - \\
\hline$\# 10$ & IA & - \\
\hline$\# 11$ & IA & - \\
\hline$\# 12$ & । & - \\
\hline$\# 14$ & I & - \\
\hline$\# 16$ & । & + \\
\hline$\# 7$ & IA & + \\
\hline$\# 13$ & I & + \\
\hline$\# 15$ & II &
\end{tabular}

nuclear staining along with cytosolic staining for IFN- $\gamma$ $\mathrm{R} \alpha$ in their tumors.

\section{Discussion}

If HER-2/neu-specific IFN- $\gamma$ producing $\mathrm{T}$ cells are involved in HER-2/neu loss and tumor recurrence, we might be able to detect such immune responses in patients with HER-2/neu negative breast cancer, who might have had undetectable HER-2/neu positive premalignant tumors in the past, that had lost HER-2/neu expression and progressed to invasive carcinoma under the immune pressure. The fact that $55-75 \%$ of patients with premalignant DCIS overexpress HER-2/neu in their tumor lesions and $75 \%$ of breast cancers are HER-2/neu negative would suggest the progression of HER-2/neu positive DCIS to HER-2/neu negative breast cancer is only in the tumor clones that express IFN- $\gamma \mathrm{R} \alpha$. We have already shown that $\mathrm{T}$ cell-mediated tumor antigen loss was due to hypermethylation of the neu promoter and loss of neu both at mRNA and protein levels [3,5]. It is likely that DNA methylation may also impact HER$2 /$ neu gene amplification, as suggested by others [13]. We performed a pilot study accruing 12 breast cancer patients with HER-2/neu negative tumors (HER-2/neu status: FISH negative) and three breast cancer patients with HER-2/neu positive tumors (FISH positive). We detected HER-2/neu-specific IFN- $\gamma$ producing $\mathrm{T}$ cell responses in PBMC of patients with HER-2/neu negative cancers (10 out of 12 patients). Interestingly, there was a direct correlation between the HER-2/neu-specific $\mathrm{T}$ cell responses and nuclear localization of IFN- $\gamma \mathrm{R} \alpha$ in the tumors, as an indication of IFN- $\gamma$ responses at the tumor site [14]. A higher IFN- $\gamma$ production in a majority of patients with HER-2/neu negative tumors compared to those with HER-2/neu positive tumors suggests the presence of high affinity $\mathrm{T}$ cells in the former. Weak $\mathrm{T}$ cell responses were associated with weak and scattered nuclear and cytosolic IFN- $\gamma \mathrm{R} \alpha$ while stronger $\mathrm{T}$ cell responses in patients with HER-2/neu- tumors was associated with an intense and uniform nuclear IFN- $\gamma \mathrm{R} \alpha$. Our findings suggest that the increased rate of HER-2/ neu positive DCIS compared with breast cancer may reflect the loss of HER-2/neu during tumorigenesis in premalignant cells where IFN- $\gamma$ signaling pathway is active. This possibility is also supported by a number of observations reported by other groups. For instance, induction of HER-2/neu-specific IFN- $\gamma$ producing $\mathrm{T}$ cell responses in patients with DCIS resulted in loss of HER-2/neu expression [7]. It was also reported that overexpression of HER-2/neu in DCIS lesions predicts the presence of invasive foci in patients with DCIS [15]. Others also have suggested that the low frequency of HER-2/neu expression (20-25\%) in invasive breast cancer implies that HER-2/neu loss is an epiphenomenon of disease progression [16].

\section{Conclusions}

The results of this study emphasize a potentially critical role for an inflammatory type of anti-tumor immune responses $[17,18]$ such as IFN- $\gamma$ which can facilitate tumor antigen loss and relapse of more invasive tumors. Presence of HER-2/neu-specific $\mathrm{T}$ cell responses in DCIS patients who have IFN- $\gamma$ R $\alpha$ positive lesions may suggest that these patients are at risk of developing HER-2/neu negative breast cancer. This needs to be determined by conducting prospective studies in patients with DCIS.

\section{Acknowledgements}

This work was supported by Massey Cancer Center Pilot Project Program 2006FPP-04 (M. H. Manjili) and VCU Presidential Research Incentive Program 145820 (M. H. Manjili). We also thank Dr. Elizabeth Bolesta for helping with the expression of the recombinant proteins.

\section{Author details}

${ }^{1}$ Department of Microbiology \& Immunology, Virginia Commonwealth University Massey Cancer Center, 401 College Street, Richmond VA 23298, USA. ${ }^{2}$ Department of Pathology, Virginia Commonwealth University Massey Cancer Center, 1200 E. Marshall Street, Richmond VA 980662, USA. ${ }^{3}$ Department of Surgery, Virginia Commonwealth University Massey Cancer Center, 1200 E. Broad Street, Richmond VA 980011, USA. ${ }^{\text {Infectious Disease }}$ and Immunogenetics Section (IDIS), Department of Transfusion Medicine, Clinical Center and Center for Human Immunology (CHI), National Institutes of Health, 10 Center Drive, Bethesda, MD 20892, USA. ${ }^{5}$ Department of Human and Molecular Genetics, Virginia Commonwealth University Massey Cancer Center, 401 College Street, Richmond VA 23298, USA.

\section{Authors' contributions}

MK prepared blood samples, monocyte-dereived dendritic cells, and performed IFN- $\gamma$ ELISA, KKP participated in drafting the manuscript and data analysis, $\mathrm{MOI}$ and MMG performed IHC analysis, LG prepared blood samples, M-LA, EW and X-YW participated in drafting the manuscript and data 
analysis, HDB coordinated clinical aspects of the study including patient's accrual and participated in drafting the manuscript, MHM conceived the study, designed the experiments, analyzed data and wrote the manuscript. All authors read and approved the final manuscript.

\section{Competing interests}

The authors declare that they have no competing interests.

Received: 2 March 2011 Accepted: 31 March 2011

Published: 31 March 2011

\section{References}

1. Beatty GL, Paterson Y: IFN-gamma can promote tumor evasion of the immune system in vivo by down-regulating cellular levels of an endogenous tumor antigen. J Immunol 2000, 165:5502-5508.

2. Hall VL, Subleski J, Back TC, Gruys ME, Shorts-Cary L, Weiss JM, Wiltrout RH: Friend or Foe? IFN Mediates Pro-Metastatic Gene Expression in the Tumor Microenvironment. J Immunol 2007, 178:48.34.

3. Kmieciak M, Knutson $\mathrm{KL}$, Dumur $\mathrm{Cl}$, Manjili MH: HER-2/neu antigen loss and relapse of mammary carcinoma are actively induced by T cellmediated anti-tumor immune responses. Eur J Immunol 2007, 37:675-685.

4. Worschech A, Kmieciak M, Knutson KL, Bear HD, Szalay AA, Wang E, Marincola FM, Manjili MH: Signatures associated with rejection or recurrence in HER-2/neu positive mammary tumors. Cancer Res 2008, 68:2436-2446.

5. Santisteban M, Reiman JM, Asiedu MK, Behrens MD, Nassar A, Kalli KR, Haluska P, Ingle JN, Hartmann LC, Manjili MH, Radisky DC, Ferrone S, Knutson KL: Immune-induced epithelial to mesenchymal transition in vivo generates breast cancer stem cells. Cancer Res 2009, 69:2887-2895.

6. Hallermalm K, Seki K, De Geer A, Motyka B, Bleackley RC, Jager MJ, Froelich CJ, Kiessling R, Levitsky V, Levitskaya J: Modulation of the tumor cell phenotype by IFN-gamma results in resistance of uveal melanoma cells to granule-mediated lysis by cytotoxic lymphocytes. J Immunol 2008, 180:3766-3774.

7. Czerniecki BJ, Koski GK, Koldovsky U, Xu S, Cohen PA, Mick R, Nisenbaum H, Pasha T, Xu M, Fox KR, Weinstein S, Orel SG, Vonderheide R, Coukos G, DeMichele A, Araujo L, Spitz FR, Rosen M, Levine BL, June C, Zhang PJ: Targeting HER-2/neu in early breast cancer development using dendritic cells with staged interleukin-12 burst secretion. Cancer Res 2007, 67:1842-1852

8. Matkowski R, Gisterek I, Halon A, Lacko A, Szewczyk K, Staszek U, Pudelko M, Szynglarewicz B, Szelachowska J, Zolnierek A, Kornafel J: The prognostic role of tumor-infiltrating CD4 and CD8 T lymphocytes in breast cancer. Anticancer Res 2009, 29:2445-2451.

9. Sheu BC, Kuo WH, Chen RJ, Huang SC, Chang KJ, Chow SN: Clinical significance of tumor-infiltrating lymphocytes in neoplastic progression and lymph node metastasis of human breast cancer. Breast 2008, 17:604-610.

10. Kominsky SL, Hobeika AC, Lake FA, Torres BA, Johnson HM: Downregulation of neu/HER-2 by interferon-gamma in prostate cancer cells. Cancer Res 2000, 60:3904-3908.

11. Dunn GP, Sheehan KC, Old L, Schreiber RD: IFN unresponsiveness in LNCaP cells due to the lack of JAK1 gene expression. Cancer Res 2005, 65:3447-3453.

12. Kmieciak M, Gowda M, Graham L, Godder K, Bear HD, Marincola FM, Manjili MH: Human T cells express CD25 and Foxp3 upon activation and exhibit effector/memory phenotypes without any regulatory/suppressor function. J Transl Med 2009, 7:89.

13. Terada K, Okochi-Takada E, Akashi-Tanaka S, Miyamoto K, Taniyama K, Tsuda H, Asada K, Kaminishi M, Ushijima T: Association between frequent CPG island methylation and HER2 amplification in human breast cancers. Carcinogenesis 2009, 30:466-471.

14. Larkin J, Johnson HM, Subramaniam PS: Differential nuclear localization of the IFNGR-1 and IFNGR-2 subunits of the IFN-gamma receptor complex following activation by IFN-gamma. J Interferon Cytokine Res 2000, 20:565-576.

15. Roses RE, Paulson EC, Sharma A, Schueller JE, Nisenbaum H, Weinstein S, Fox KR, Zhang PJ, Czerniecki BJ: HER-2/neu overexpression as a predictor for the transition from in situ to invasive breast cancer. Cancer Epidemiol Biomarkers Prev 2009, 18:1386-1389.
16. Hoque A, Sneige N, Sahin AA, Menter DG, Bacus JW, Hortobagyi GN, Lippman SM: Her-2/neu gene amplification in ductal carcinoma in situ of the breast. Cancer Epidemiol Biomarkers Prev 2002, 11:587-590.

17. Amsen D, de Visser KE, Town T: Approaches to determine expression of inflammatory cytokines. Methods Mol Biol 2009, 511:107-142.

18. de Visser KE: Spontaneous immune responses to sporadic tumors: tumorpromoting, tumor-protective or both? Cancer Immunol Immunother 2008, 57:1531-1539.

doi:10.1186/1479-5876-9-35

Cite this article as: Kmieciak et al:: Tumor escape and progression of HER-2/neu negative breast cancer under immune pressure. Journal of Translational Medicine 2011 9:35.

\section{Submit your next manuscript to BioMed Central and take full advantage of:}

- Convenient online submission

- Thorough peer review

- No space constraints or color figure charges

- Immediate publication on acceptance

- Inclusion in PubMed, CAS, Scopus and Google Scholar

- Research which is freely available for redistribution

Submit your manuscript at www.biomedcentral.com/submit
Ciomed Central 